\title{
MODEL PEMBELAJARAN PENDIDIKAN AGAMA ISLAM DI SEKOLAH UMUM
}

\author{
Winda Agustina ${ }^{1}$, Hamengkubuwono ${ }^{2}$, Wandi Syahindra ${ }^{3}$, \\ 1,2,3 Institut Agama Islam Negeri (IAIN) Curup, Bengkulu \\ Email:windaagustina848@gmail.com; hamengku7@gmail.com
}

\begin{abstract}
Abstrak
Penelitian ini bertujuan untuk menemukan gambaran model pembelajaran PAI di sekolah SMKN Lubuk Ubar Kabupaten Rejang Lebong, Bengkulu. Penelitian ini menggunakan pendekatan kualitatif dan sumber datanya adalah guru PAI, guru kelas dan kepala sekolah. Penelitian ini menggunakan teknik observasi dan wawancara untuk mengumpulkan data yang berkaitan dengan tujuan penelitian. Setelah data terkumpul tahapan selanjutnya adalah menangalisis data, dalam hal ini penelitin menggunakan pendekatan Miles dkk yaitu, memilihan data dan pemetaan data, penyajian data dan perivikasi dan kesimpulan. Penelitian ini menemukan kesimpulan sebagai berikut: model pembelajaran yang diterapkan oleh guru PAI adalah pertama model pembelajaran aktif dan kooperatif, yaitu model pembelajaran yang membawa siswa menjadi aktif dan kreatif, tidak hanya sekadar mendengarkan, akan tetapi juga melakukan kegiatan seperti memproses, menemukan, dan memanfaatkan informasi. Kedua, model pembelajaran kontektual, model ini membantu pendidik mengaitkan antara materi yang diajarkan dengan situasi dunia nyata peserta didik, sehingga membuat peserta didik dapat menemukan hubungan antara pengetahuan yang dimilikinya dengan penerapanya dalam kehidupan mereka sebagai anggota keluarga dan masyarakat.
\end{abstract}

Kata kunci: Model Pembelajaran, PAI, Sekolah umum

\begin{abstract}
This study aimed to find out a depiction of PAI learning model at SMKN of Lubuk Ubar in Rejang Lebong, Bengkulu. This study used a qualitative approach, and the data sources were PAI teacher, class teacher, and school principal. This study used observation and interview techniques to gather data as regards objectives of this study. After the data were collected, the next step was to analyze the data using the approach of Miles et al comprised of selecting and mapping data, presenting data, and verifying conclusion. This study drew the following conclusion: the learning model applied by PAI teachers was first an active and cooperative learning model. It referred to a learning model that led students to be active and creative, not just listening, but also carrying out activities such as processing, finding, and utilizing information. Second, the contextual learning model, this model helped educators link between the materials taught and real-world situations experienced by students, so that students could find a relationship between the knowledge they had and its application in their lives as family and community members.
\end{abstract}

Keywords: Learning Model, PAI, Public Schools 


\section{A. PENDAHULUAN}

Pendidikan merupakan kebutuhan manusia dan tidak bisa dipisahkan dengan terjadinya proses meningkatkan kecerdasan dan faktor pendewasaan manusia (Anasri, 2019; Anwar, 2018). Pendidikan bisa saja berawal dari sebelum bayi lahir seperti yang dilakukan oleh banyak orang dengan memainkan musik dan membaca ketika bayi dalam kandungan dengan harapan ia bisa mengajar bayi mereka sebelum kelahiran (Ariyanti, 2016; Daheri \& Warsah, 2019; Kusumawati, 2016).

Dalam Kamus Bahasa Indonesia kata pendidikan berasal dari kata 'didik' dan mendapat imbuhan 'pe' dan akhiran 'an', maka kata ini mempunyai arti proses atau cara atau perbuatan mendidik. Secara bahasa definisi pendidikan adalah proses pengubahan sikap dan tata laku seseorang atau kelompok orang dalam usaha mendewasakan manusia melalui upaya pengajaran dan pelatihan (E. Setiawan, 2012). Ki Hajar Dewantara menjelaskan tentang pengertian pendidikan yaitu: pendidikan yaitu tuntutan di dalam hidup tumbuhnya anak-anak, adapun maksudnya, pendidikan yaitu menuntun segala kekuatan kodrat yang ada pada anak-anak itu, agar mereka sebagai manusia dan sebagai anggota masyarakat dapatlah mencapai keselamatan dan kebahagiaan setinggi-tingginya (Hidayah, 2015; Magta, 2013; Mustaqim, 2017).

Beberapa definisi di atas memberikan gambaran bahwa pendidikan adalah bimbingan atau pertolongan yang diberikan oleh orang dewasa kepada perkembangan anak untuk mencapai kedewasaannya dengan tujuan agar anak cukup cakap melaksanakan tugas hidupnya sendiri tidak dengan bantuan orang lain. Dengan kata lain, pendidikan mempunyai tujuan yang akan dicapai manusia dalam menjalani kehidupan mendatang. Tujuan dari pendidikan adalah untuk menjadi manusia atau individu yang bertaqwa dan beriman kepada Tuhan YME, mempunyai akhlak mulia, cerdas, sehat, berkemauan, berperasaan, dan dapat berkarya untuk memenuhi kebutuhan secara wajar, dapat mengendalikan hawa nafsu, bermasyarakat, berbudaya, dan berkepribadian (Warsah, 2018). Implikasi dari pendidikan mampu mewujudkan atau mengembangkan segala potensi yang ada pada diri manusia dalamberbagai konteks dimensi seperti moralitas, keberagaman, individualitas (personalitas), sosialitas, keberbudayaan yang menyeluruh dan terintegrasi. Dapat dikatakan juga bahwa pendidikan mempunyai fungsi untuk memanusiakan manusia (Abdul et al., 2020; Warsah et al., 2020).

Model pembelajaran yang menarik dan disampaikan secara menarik pula akan meningkatkan motivasi belajar peserta didik (Ardiana, 2018; Astuti \& Kristin, 2017; Haeruman et al., 2017). Cara pendidik yang menyampaikan materi pelajaran melalui contoh-contoh ilustrasi tentang kehidupan sehari-hari atau cara pendidik menyampaikan manfaat dari mempelajari pokok-pokok bahasan yang dipelajari akan sangat mempengaruhi motivasi belajar peserta didik pembelajaran merupakan suatu preses membelajarkan peserta didik agar dapat mempelajari sesuatu yang relevan dan bermakna bagi diri mereka di samping itu juga untuk mengembang kan pengalaman belajar dimana peserta didik dapat secara aktif menciptakan apa yang sudah diketahuinya dengan pengalaman yang diperoleh (Emda, 2018; Syaparuddin et al., 2020).

Model pembelajaran dapat didefinisikan sebagai desain pengajaran (instruksional) yang menggambarkan (mendeskripsikan) proses khusus dan penyediaan iklim belajar tertentu yang dapat membuat peserta didik berinteraksi sedemikian rupa sehingga terjadi perubahan perilaku misalnya dari tidak tahu menjadi tahu (Dewi et al., 2016; Laili, 2016). Pendapat yang lebih sederhana menyebutkan bahwa model pembelajaran adalah standar tingkah laku dalam mengajar 
yang teridentifikasi agar dapat mencapai situasi mengajar tertentu, dalam rangka mencapai tujuan pendidikan seperti yang telah dibahas di atas maka dibutuhkan penyelnggaraan pembelajaran yang bermutu, efektif dan efisien tentu disertai dengan disain, model, atau strategi pembelajaran yang digunakan dalam suatu lembaga penyelenggara pendidikan tersebut (Desstya et al., 2017; Ekawati et al., 2016; Elyas, 2018; Jamil, 2019).

Membahas tentang kegiatan pengajaran serta bimbingan PAI, berdasarkan visi dan misi tersebut tentu dibutuhkan beberapa upaya yang perlu dikerahkan oleh pihak sekolah sebagai suatu sebagai suatu lembaga penyelenggaraan pendidikan tingkat dasar maupun menengah agar bernuansa Islami terutama berkaitan dengan pendidikan Agama Islam yang bertujuan untuk membina peserta didik agar senantiasa mengetahui memahami, meyakini, dan mengamalkan ajaran agama Islam dalam kehidupan sehari-hari.

Model pembelajaran dapat disimpulkan menjadi suatu rancangan atau pola yang didesain oleh pendidik dalam mengajar untuk mencapai tujuan pembelajaran (Nurdyansyah, 2016; A. Setiawan \& Basyari, 2017). Dengan adanya model pembelajaran pendidik dapat menentukan pembelajaran yang ingin dilakukan untuk membuat peserta didik nyaman dalam belajar dan paham dengan apa yang diajarkanya, untuk mencapai tujuan pembelajaran. Model pembelajaran merupakan suatu rancangan yang didalamnya menggambarkan sebuah proses pembelajaran yang dapat dilaksanakan oleh guru dalam mentransper pengetahuan maupun nilai-nilai kepada siswa (Dewi et al., 2016; Marzuki, 2017; Ngazizah, 2019). Sedangkan Pendidikan Agama Islam (PAI) merupakan usaha sadar dan terencana untuk menyiapkan siswa dalam meyakini, memahami, menghayati dan mengamalkan ajaran Islam melalui kegiatan bimbingan, pengajaran dan latihan (AHMADI, 2017; Asnawan, 2020; Fachri, 2014).

Jadi, model pembelajaran Pendidikan Agama Islam merupakan suatu rancangan yang di dalamnya menggambarkan sebuah proses pembelajaran yang dapat dilaksanakn oleh guru dalam menstransfer pengetahuan maupun nilai-nilai kepada peserta didik sehingga diharapkan peserta didik dapat meyakini, memahami, menghayati dan mengamalkan ajaran Islam (Ilham, 2019; Sutiah, 2020; Yasyakur, 2017). Sasaran dan tujuan pembelajaran yakni perubahan perilaku serta rangkaian kegiatan yang harus dilakukan sebagai upaya pencapaian tujuan tersebut dengan memanfaatkan segala potensi dan sumber belajar yang ada.

Gambaran ideal tersebut tidak selamanya dikuasai oleh pendidik. Banyak pendidik yang tidak menguasai model maupun metode ketika diaplikasikan dalam proses belajar mengajar. Sistem hafalan (kemanpuan Kognititif peserta didik) menjadi lebih dominan dari pada dialog, rasa ingin tahu, ide segar, orisinilitas, inovasi sehingga kreatifitas peserta didik sebagai manusia unik menjadi terhambat (Warsah \& Nuzuar, 2018). Terlebih lagi pembelajaran Pendidikan Islam terkesan menjadi pendidikan kelas dua di sekolah umum, terbukti dengan jam pelajaran yang begitu minim.

Upaya mengantidipasi hal emage tersebut, guru haru melakukan inovasi dan kreativitas agar pelaksanaan pembelajaran dapat belajar dengan efektif. Inovasi dan kreativitas guru didemonstrasikan dalam bentuk keterampilan-keterampilan dan kecapakan menggunakan metode dan media pembelajaran. Metode mengajar diartikan sebagai suatu pengetahuan tentang caracara mengajar atau teknik pengajian yang dikuasai guru untuk mengajar, atau menyajikan bahan pelajaran kepada siswa di depan kelas, baik secara individual maupun kelompok agar pelajaran 
tersebut dapat diserap, dipahami, dan dimanfaatkan oleh siswa dengan baik (Nasution, 2018; Syaodih \& Wulansari, 2019).

Sementara bahan ajar atau materi pelajaran merupakan segala sesuatu yang oleh pendidik diberikan secara langsung kepada peserta didik dalam rangka mencapai tujuan pendidikan (Amin, 2017; A. Setiawan \& Basyari, 2017; Zuhdiyah, 2018). Tentu ada syarat utama dalam pemilihan materi pendidikan yaitu materi harus sesuai dengan tujuan pendidikan dan juga harus sesuai dengan tingkat perkembangan peserta didik.

Mencermati deskripsi alur dan esesnsi model pembelajaran di atas, pendidik mempunyai peran sebagai pengajar yang menyampaikan materi ajar dengan sebaik mungkin untuk mencapai tujuan pembelajaran. Kreatifitas mengajar diperlukan oleh seorang pendidik agar apa yang diajarkan bisa dipahami dan cernati oleh peserta didik. Model pelajaran yang digunakan pendidik seperti medel berbasis IMTAQ di sekolah umum seperti di SMKN Lubuk Ubar, Rejang Lebong, Bengkulu dapat menjadi terobosan untuk mengintegralkan pesan-pesan keislaman kedalam materi pelajaran yang bersifat umum (Observasi, 22 Januari 2020).

Penyampaian bahan pelajaran untuk mencapai tujuan yang ditetapkan, fungsinya adalah menentukan berhasil tidaknya suatu proses belajar mengajar dan merupakan bagian yang tidak dapat terpisahkan dalam suatu sistem pengajaran. Oleh karena itu metode harus sesuai dan selaras denga karakteristik siswa, materi kondisi dan lingkungan, dapat disimpulkan bahwa model pengajaran PAI menggunakan metode ceramah sudah sejak lama digunakan dalam kegiatan pembelajaran tentu akan menimbulan kejenuhan siswa dalam menerima materi pendidikan Agama Islam, meskipun demikian model pembelajaran dengan motede ceramah ini memungkinkan siswa dapat berkembang dengan cepat jika dikolaborasikan dengan metodemetode yang lain.

Peneliti melakukan penelitian di SMK 3 Lubuk Ubar, Curup Selatan. Sekolah tersebut berada di wilayah Kabupaten Rejang Lebong. Sekolah ini tidak mempunyai target input dalam penerimaan peserta didik. Latar belakang peserta didik yang berbeda dari segi karakter maupun kecerdasan membuat pendidik harus cerdas dan cermat dalam menerapkan model pembelajaran yang digunakan. Karena kondisi tersebut, sekolah ini membutuhkan suatu usaha atau upaya dalam mengembangkan keberagamaan peserta didiknya. Hal tersebut menjadi tugas yang berat bagi pendidik untuk mengantarkan peserta didik menjadi manusia yang mampu menerapkan ajaran agama Islam dalam keluarga dan masyarakat.

Sekolah ini mempunyai suatu model pembelajaran untuk meningkatkan keberagamaan peserta didik melalui pendidikan Agama Islam yang mengantarkan peserta didik mencapai tujuan pembelajaran. Upaya yang dilakukan oleh guru dalam peningkatan hasil belajar siswa dalam ranah kognitif tersebut perlu dicermati lebih lanjut melalui penelitian ilmiah, sehingga peneliti tertarik untuk meneliti lebih lanjut model pembelajaran apa saja yang diterapkan di SMK 03 Lubuk Ubar Kabupeten Rejang Lebong. Terutama dalam mata pelajaran Pendidikan Agama Islam.

\section{B. METODE PENELITIAN}

Penelitian ini menggunakan pendekatan kualitatif. Moleong menjelaskan penelitian kualitatif adalah penelitian yang bermaksud untuk memahami fenomena tentang apa yang dialami oleh subjek penelitian misalnya perilaku, persepsi, motivasi, tindakan, secara holistik, 
dan dengan cara deskripsi dalam bentuk kata-kata dan bahasa, pada suatu konteks khusus yang alamiah dan dengan memanfaatkan berbagai metode ilmiah (Moleong, 2010). Dalam penelitian ini peneliti bertindak sebagai instrumen sekaligus menjadi pengumpul data. Instrument lain yang digunakan penulis adalah alat, note book atau catatan serta alat dokumentasi (Semiawan, 2010). Akan tetapi instrumen ini hanya sebagai pendukung tugas penulis sebagai instrument (Sugiarto, 2017; Suwendra, 2018).

Penelitian dilaksanakan di SMK 3 Lubuk Ubar, Kecamatan Curup Selatan, Kabupaten Rejang Lebong. Informan digunakan sebagai sumber data dan aktor atau pelaku yang ikut menentukan berhasil tidaknya sebuah penelitian berdasarkan informasi yang diberikan. Informan dalam penelitian ini adalah guru mata pelajaran pendidikan Agama Islam yang dijadikan sebagai sumber data dengan melakukan wawancara. Selain informan di atas ada beberapa informan tambahan sebagai pembanding yaitu peserta didik untuk mengklarifikasi kebenaran penggunaan model pembelajaran yang digunakan pendidik. Prosedur pengumpulan data yang dilakukan dalam penelitian ini adalah observasi nonpartisipan di mana peneliti tidak banyak dituntut peranan tingkah laku atau keterlibatannya terhadap kegiatan atau fenomena dari subjek yang diteliti. Perhatian peneliti terfokus pada bagaimana mengamati, merekam, memotret, mempelajari dan mencatat tingkah laku atau fenomena yang diteliti (A. A. Setiawan Johan, 2018). Observasi ini bersifat terbuka karena diketahui oleh subjek yang diteliti. Wawancara adalah percakapan langsung dan tatap muka dengan maksud tertentu. Wawancara ini dilakukan kepada pendidik untuk mendapatkan informasi tentang model pembelajaran yang digunakan pada materi pendidikan Agama Islam dan hambatan yang ditemukan dalam proses belajar mengajar guna mendukung penelitian (Roulston, 2014).

Setelah data diperoleh, tahap selanjutnya adalah melakukan analisis data. Dalam hal ini peneliti menggunakan analisis data kualitatif, di mana data dianalisa dengan metode diskriptif analisis non statistik yang meliputi cara berfikir induktif yaitu peneliti berangkat dari pengetahuan yang bersifat khusus untuk menilai suatu kejadian umum dengan tahapan memilih data/reduksi data yang telah terkumpul, menyajikan sehingga diperoleh simpulan sebagai jawaban tujuan penelitian yang telah dirumuskan dalam pendahuluan yakni tentang model pembelajaran PAI di SMK 3 Lubuk Ubar Curup Selatan kabupaten Rejang Lebong (Hashimov, 2015; Miles et al., 2014).

\section{HASIL DAN PEMBAHASAN}

\section{Hasil Pembahasan}

Pada observasi pertama masuk sekolah SMK 3 Lubuk Ubar kecamatan Curup Selatan ini, selain menemui kepala sekolah, tentu juga menemui informasi utama yaitu guru PAI di sekolah tersebut: ternyata di sekolah ini terdapat dua orang Guru PAI yaitu Sasmahera, S.Pd.I,M.Pd, ibu Eli Hazizah, M.Pd dan ibu Latifah S.Pd juga diberi tugas tambahan sebagai pembina imtak di sekolah tersebut. Adapun informasi yang diperoleh adalah sebagai berikut: pada pertanyaan penelitian pertama tentang:

\section{a. Model pembelajaran yang digunakan dalam pembelajaran Pendidikan Agama Islam}

Guna memperoleh informasi tentang model pembelajaran Pendidikan Agama Islam di SMK Lubuk Ubar Curup Selatan, penulis memberikan beberapa pertanyaan sebagai berikut: 
Model apa saja yang digunakan dalam pembelajaran PAI di SMK 3 Lubuk Ubar? Menurut ibu Eli Hazizah, M.Pd: "Dikarenakan latar pendidikan saya adalah PAI, maka dalam mengajar PAI di sekolah ini saya sering melibatkan anak dalam belajar. Atau kalau dalam istilah teori model pembelajaran saya menggunakan model pembelajaran aktif atau sering disebut dengan active learning. Di sini siswa kami ajak untuk berperan aktif dalam setiap pembelajaran berlangsung" (Wawancara dengan ibu Eli Hazizah, M.Pd di ruang guru pada hari Kamis, 13 Februari 2020).

Lain halnya dengan guru PAI lainnya, ibu Latifah S.Pd. pada saat ditanya dengan pertanyaan yang sama tentang medel pembelajaran apa yang sering digunakan oleh sauadara dalam memberikan matpa yang sering digunakan oleh sauadara dalam memberikan materi PAI dan pembinaan imtak siswa SMK 3 Lubuk Ubar? Menanggapi pertanyaan ini beliau mengatakan bahwa:

"Saya berusaha mencari dan menggali infomasi baik kepada ibu Eli maupun melalui buku, sehingga saya tidak terpaku memilih model apa pada saat saya mengajar PAI di kelas. Namun demikian saya sering "kalau boleh dibilang" melakukan pendekatan model pembelajaran kontektual, karena menurut saya pribadi bahwa pembelajaran PAI bukan hanya harus diketahui dengan dihafal namun juga harus difahami dan caranya antara lain mengaitkan isi materi dengan problem yang terjadi di lapangan (Wawancara, 13 Februari 2020).

Menurut ibu Sasmahera, S.Pd.I, M.Pd bagaimana pelaksanaan penggunaan model pembelajaran pendidikan agama islam bahwa:

"Penerapan model pembelajaran yang sesuai menjadi salah satu jalan dalam upaya pencapaian tujuan pembelajaran agama islam sehingga menjadi manusia yang bertakwa dan berahlak mulia,penggunaan model pembelajaran di sini ialah tentang bagaimana seoraang guru memilih model pembelajaran yang tepat sesuai karakter siswa ,keadaan lingkungan (sarana dan prasarana)dan masih banyak lainnya sehingga untuk mencapai suatu tujuan pembelajaran secara efektif dan efisien itu,tentu menjadi suatu keharusan guru bekerja sama dengan pihak sekolah serta peserta didik menggunakan model pembelajaran yang paling sesuai" (Wawancara, 13 Februari 2020).

Informasi dari informan di atas, menegaskan bahwa model pembelajaran apa saja dapat digunakan dalam proses pembelajaran PAI, hal ini terbukti bahwa para guru PAI di SMK 3 Lubuk Ubar menerapkan model pembelajaran pada materi PAI cukup bervariasi, ada yang menggunakan model pembelajaran aktif ada juga yang menggunakan model pembelajaran kontektual. Tentu dengan tujuan agar mapel PAI tidak membosankan siswa dalam kelas. Pertanyaan selanjutnya adalah; Bagaimana penerapan model-model pembelajaran tersebut?.

"Tentu dalam pembelajaran kami memperiapkan prangkat pembelajaran seperti silabus dan RPP, dan tema materi pembelajara tersebut telah disampaikan kepada anak didik kamu sesudah pelajaran sebelumnya tertutup. Hal ini dilakukan agar anak kami dapat mempelajari dan mempersiapkan diri jika nanti kami menggukan metode debat aktif atau metode lainnya" (Wawancara 10 Februari 2020)

Hal ini dibenarkan oleh ibu Latifah, dengan mengatakan bahwa:

"Memang setiap akan melaksanakan proses belajar mengajar silabus materi PAI di sekolah ini masing-msing kami seragam. Artinya silabus dan RPP sudah tersedia dengan mengesuaikan dengan buku ajar yang telah ditentukan oleh pemerintah. Nah kalau persiapan yang saya lakukan dalam menerapkan model pembelajaran tersebut, saya 
pelajarai dulu materi apa yang akan saya berikan pada hari ini, maka saya akan menggali lebih dalam keterkaitan materi tersebut dengan hal-hal yang lain malalui sumber yang saya miliki. Selanjutnya pada saat akhir materi siswa diminta untuk merangkum materi yang ada dan minta untuk membuat contoh dalam kehidupan yang nyata berdasarkan pengalaman mereka masing-masing" (Wawancara 13, Februari 2020).

Tentu dalam setiap proses pembelajaran, beberapa perangkat pembelajaran harus disiapkan, termasuk pendekatan apa yang akan digunakan menjadi penting. Tahapan-tahapan pelaksanaan model apa yang akan digunakan tentu mengacu pada teori model-medel pembelajaran yang ada. Model pembelajaran aktif misalnya, tentu guru harus melakukan tahapan dengan cara memilih pendekatan yang ada seperti perangkat permainan kartu acak jika menggunakan pendekatan tersebut. Membuat kelompok pro dan kontra dan memberi tema materi sebagai bahan berdebat dan lain-lain. Pertanyaan selanjutnya yang penulis tanyakan kepada guru tersebut adalah "Apakah model pembelajaran yang diterapkan membuat siswa senang dan bersemangat belajar?"

"Tentu, karena pada dasarnya, masalah yang sering terjadi di sekolah umum seperti ini, mata pelajaran PAI tidak begitu diminati oleh siswa karena banyak hal, seperti, tidak menjadi syarat kelulusan dan jam pelajarannya sedikit, sehingga cenderung disepelekan oleh sebagian siswa. Untuk itulah kita perlu melakukan inovasi dengan menggunakan beberapa pendekatan seperti model pembelajaran kooperatif, di mana siswa dapat berperan aktif dalam pembelajaran tersebut, diskusi bersama, aktif dalam debat antar kelompok dan terkadang kami gunakana metode game agar mereka tidak bosan menerima materi PAI yang selama ini terkesan monoton. Yah ternyata mereka cukup bersemangat kok untuk mengikuti materi kita. Apalagi setiap proses pembelajaran mereka diikut sertakan berperan aktif dalam pembelajaran" (Wawancara, 13 Februari 2020).

Hal yang sama juga disampaikan oleh ibu Latifah: "Saya melihat, motivasi siswa dalam belajar PAI memang dirasakan kurang, namun setelah kami malakukan terobosan dalam beberapa semester ini, terlihat perubahan mereka rajin dan aktif mengikut pelajaran PAI di kelas. Termasuk ketika kami membuat beberapa program ekstra sebagai penungjang peningkatan imtak di sekolah ini, mereka bersemangat dan bahkan ikut berpartisipasi dalam kegiatan keagamaan di sekolah, sperti shalat Zuhur berjamaan, acara PHBI di sekolah dan lain-lain (Wawancara, 15 Februari 2020).

Secara teoretis memang, peran guru dalam proses pembelajaran adalah salah salah satu faktor dalam meningkatkan motivasi belajar siswa. Model dan pendekatan yang digunakan guru dalam proses tersebut menjadi penting. Apalagi pada pelajaran yang dianggap mudah dan membosankan. Guru harus cermat memperhatikan kondisi siswa. Dengan kondisi tersebut, tentu diharapkan guru dapat menjadi lebih kreatif untuk melakukan terobosan-terobosan baru dalam memberikan materi aja sehingga pembelajaran yang dilakukan lebih bermakna dan siswa meningkat minat dan motivasinya dalam belajar.

Pertanyaan selanjutnya adalah "Apakah model yang dipilih disesuaikan dengan materi yang akan diberikan kepada siswa?" menurut pendapat ibu Eli Hazizah M.Pd: "Kalau selama pembelaran PAI model pembelajaran aktif relevgan dengan materi PAI yang ada. Apalagi pendekatan pada model tersebut cukup banyak bu, dan itu dibisa disuaikan dengan materi yang 
ada. Misalnya materi tentang zakat harta dan zakat fitrah, ini bisa dilakukan dengan metode diskusi debat aktif begitu juga dengan materi lain (Wawancara, 13 Februari 2020).

Pendapat yang sama juga disampaikan oleh ibu Latifah:” pada materi PAI memang seharusnya siswa diarahkan untuk menggali informasi dalam mengkolaborasikan materi PAI dengan realitas di lapangan. Jadi artinya materi ajar PAI dengan model yang digunakan tentu terdapat persesuaian sehingga diharapkan pembelajaran PAI lebih bermakna bagi setiap siswa" (Wawancara, 15 Februari 2020).

Pada pertanyaan selanjutnya yang tidak kalah penting adalah "apakah model yang digunakan dapat meningkatkan hasil belajar PAI siswa menjadi lebih baik?" menurut ibu Eli Hazizah M.Pd bahwa: "Alhamdulillah, hasil belajar PAI siswa kami di SMK 03 Lubu Ubar ini memcapai KKM semua. Di samping itu, semangat untuk mengikuti kegiatan keagamaan di sekolah pun semakin meningkat menjadi lebih baik (Wawancara, 14 Februari 2020).”

Hal ini ditambahkan oleh ibu Latifah: "memang betul apa yang disampaikan oleh ibu Eli, memang model pembelajaran yang kami terapkan berdampak positif bagi hasil belajar siswa kami di sini. Mereka senang belajar PAI apalagi ketika kami mengajak mereka belajar di luar kelas dan melakukan pengamatan di lingkung sekitar, wah mereka bersemangat sekali (Wawancara, 15 Februari 202).

Tujuan dari model maupun pendekatan dalam pelaksanaan pembelajaran tersebut berhasil tidak pada akhirnya akan dilihat dari hasil akhir setiap semester dan akan terlihat dari perubahan perilaku masing-masing siswa. Ketika proses pembelajaran dianggap baik, model dan pendekatan dianggap menyenangkan tentu akan berdampak positif bagi siswa. Melalui proses yang baik, tentu hasil pelajar baik secara kognitif, afektif dan psikomotorik akan menjadi lebih baik.

Pertanyaan terakhir guna untuk melengkapi data pertanyaan penelitian pertama adalah "Apa saja indikator peningkatan hasil belajar PAI siswa selama menggunakan model-model pembelajaran?" seperti telah dijelaskan sebelumnya, papar ibu Eli Hazizah dan ibu Latifah: "Kita bisa lihat beberapa indikator keberhasilan siswa seperti, nilai siswa lulus dari KKM bahkan banyak yang melampaui KKM yang tentukan, etika mereka menjadi semakin baik, mayoritas siswa mengikuti shalat Zuhur berjamaah di sekolah meskipun tidak ada aturan sekolah yang mewajibkan selama satu tahun 20113-2020 yang sebelumnya kurang termotivasi". Tambah ibu Latifah: "berperan serta dalam berbagai kegiatan keagamaan seperti memeriahkan hari besar Islam yang diawali dengan lomba-lomba dan lain-lain sehingga semua menjadi lebih baik maka dari itu harus dimulai dengan kebiasaan (Wawancara dengan ibu Eli dan Latifah, 14 Februari 2020).

Sesungguhnya, indikator keberhasilan pada pembelajaran PAI, tidak bisa hanya dilihat dari satu sisi, seperti nilai siswa setiap akhir semester tapi juga yang tidak kalah penting adalah perubahan prilaku siswa, apakah setelah berakhirnya proses belajar prilaku mereka menjadi lebih baik. Inilah indikator keberhasilan pembelajaran PAI yang tidak bisa diukur melalui nilai namun dapat diamati dari interaksi mereka di sekolah dan di rumah. Tentu untuk mempertahankan hal tersebut perlunya kerja sama guru dan orang tua siswa. Hal ini penting karena guru tidak dapat menjangkau aktivitas siswa di rumah maupun diluar sekolah . 


\section{b. Faktor pendukung dan penghambat dalam menerapkan model pembelajaran Pendidikan Agama Islam}

Setiap proses belajar mengajar tentu ditemukan faktor pendukung maupun faktor penghambat. Berkenaan dengan hal itu maka peneliti akan menanyakan beberapa hal tentang faktor pendukung dan penghambat penerapan model pembelajaran tersebut. Pertanyaan tersebut antara lain: Bagaimana respons kepala sekolah dan guru lain ketika menerapkan model-model pembelajaran pada materi PAI di SMK 03 Lubu ubar?

"Kepala sekolah memang memberikan pengarahan kepada setiap guru agar dapat selalu malakukan inovasi dalam proses belajar. Tentu dukungan dari kepala sekolah pada setiap guru sangat positif, termasuk kepada kami guru-guru pendidikan agama Islam. Dengan demikian kamipun tidak malu bertanya dan bertukar pendapat dengan kepala sekolah dan para dewan guru lain tentang terobosan yang akan dilakukan (Wawancara de, 24 Februari 2020)

Hal yang sama juga disampaikan oleh ibu Latifah yang mengataka bahwa: "dukungan dari kepala sekolah menjadi factor penting dalam setiap aktivitas pendidikan yang kami lakukan. Sebulan sekali sekolah melakukan evaluasi pada setiap guru, dan mengumpulkan guru dalam pertemuan bulanan, selain sabagai media silaturrahmi pertemuan tersebut menjadi wadah untuk saling berbagi informasi (Wawancara, 24 Februari 2020)"

Dalam kesempatan yang sama, peneliti sempat menemui kepala sekolah di ruang kerjanya dan memberikan informasi sebagai berikut:

"Kami sebagai guru yang dimandat oleh pemerintah untuk memiliki tugas tambahan sebagai kepala sekolah di SMK 03 Lubuk Ubar ini, tentu memberikan dukungan penuh terhadap terobosan bagi para dewan guru, bahkan kami telah mempuyai program pertemuan sebulan sekali di sekolah dan di sanalah kami berkesempatan memberikan arahan kepada para guru agar melaksanakan pembelajaran dengan ikhlas hati, dan malakukan terobosan baru dalam proses pebelajaran (Wawancara, 24 Februari 2020).

Berdasarkan informasi di atas, tergambar jelas bahwa, pembinaan kepala sekolah, menjadi faktor pendukung dalam menerapkan model-model pembelajaran di sekolah. Tentu tanpa dukungan pihak sekolah, apapun yang dilakukan oleh guru tidak akan diapresiasi oleh kepala sekolah. Pertanyaan selanjutnya adalah; "Apakah model yang digunakan dibantu dengan media pembelajaran di sekolah?"

"Setiap model pembelajaran yang diterapkan akan lebih baik menggunakan media pembelajaran, seperti media audio dan visual. Alhamdulillah di sekolah ini telah memiliki media tersebut dan kami dapat menggunakan media tersebut dalam melaksakan proses belajar mengajar. Penggunaan media ini cukup membantu kami dalam menerapkan model pembelajaran dalam pelajaran PAI di SMK 03 Lubu Ubar. Pernyataan yang sama juga disampaikan oleh ibu guru Latifah, akan penting media pembelajaran dalam proses pendidikan, dan menjadi penunjang bagi terlaksananya model-model pembelajaran PAI yang kami terapkan di sekolah (Wawancara, 24 Februari 2020).

Pertanyaan selanjutnya adalah: "Apakah guru membuat panduan pelaksanaan model sebelum proses belajar dilaksanakan?" Menurut para guru PAI SMK 03 Lubuk Ubar memaparkan bahwa: "Dalam penerapkan model-model pembelajaran kami tentu menyiapkan panduan yang sesuai dengan tuntunan dalam model pembelajaran tersebut. Hal ini agar 
memudahkan kami untuk menerapkan model tersebut sesuai dengan tahapan yang benar agar tujuan pembelajaran tercapai dengan baik" (Wawancara, 25 Februari 2020).

Pertanyaan selanjutnya: "Apa saja hambatan yang ditemukan guru dalam menerapkan model pembelajaran pada saat memberikan materi PAI di SMK 03 Lubuk Ubar? Menurut para guru PAI; kami dalam pelaksanaan pembelajaran tidak menemukan hambatan yang berarti. Jika masih ada satu, dua siswa yang masih belum begitu aktif dalam proses belajar, tidak menjadi hambatan yang berarti ((Wawancara, 25 Februari 2020).

Bagaimana tanggapan siswa tentang model yang digunakan guru dalam pembelajan PAI? Untuk menjawab pertanyaan ini kami berusaha menemui beberapa siswa kelas X, mayoritas mereka dapat disimpulkan berpendapat bahwa pembelajaran PAI menarik jika model dan pendekatan yang dilakukan oleh guru seperti tersebut. Mereka merasa proses pembelajaran PAI diikutsertakan dan diberikan tanggungjawab dan diberi kesempatan untuk mengembangkan materi tersebut sesuai dan wawasan dan pengalaman mereka masing-masing.

Berdasarkan beberapa argumentasi di atas, tergambar beberapa factor pendukung dan penghambat dalam penerapkan model pembelajaran dalam rangka meningkatkan hasil pembelajaran PAI siswa kelas X SMK Negeri Lubuk Ubar lain: dukungan, pembinaan dan apresiasi dari kepala sekolah; berbagi pengalaman dan informasi serta media pembelajaran yang tersedia di sekolah tersebut menjadi factor pendukung terlaksananya penerapan model pembelajaran PAI di kelas. Adapun factor penghambat yang prinsip belum banyak ditemukan oleh guru.

Dengan demikian jelaslah bahwa model-model pembelajaran merupakan contoh kreatifitas guru dalam melaksanakan tugasnya memberi pembelajaran di kelas, dengan harapan, model, pendekatan, dan media pembelajan yang digunakan oleh guru dapat memberikan jalan kepada guru untuk mencapai tujuan yang ingin dicapai dalam proses pendidikan. Proses pembelajaran yang baik akan menciptakan kondisi belajar yang bermakna dan pada akhirnya para siswa akan memperoleh hasil yang baik.

\section{Pembahasan}

Hakikat dari tujuan dari belajar adalah agar peserta didik mengalami perubahan dari tingkah laku. Perubahan tingkah laku tersebut biasanya permanen atau jangka panjang yang membawa perubahan aktual maupun potensial (Noor, 2018; Saihu, 2019; Syafe'i, 2015). Perubahan belajar juga memberikan kecakapan baru bagi seseorang dan perubahan itu terjadi karena adanya usaha atau disengaja. Paling tidak perubahan perilaku sebagai indikator keberhasilan belajar menurut Syah dalam Arifin memilik tiga ciri yang dapat diamati (Arifin, 2017):

a. Perubahan Intensional, sebuah perubahan melalui proses pembelajaran dan perubahan tersebut disadari oleh peserta didik dan mereka dapat merasakan aspek apa saja yang mereka peroleh setelah mengikuti proses pembelajaran.

b. Perubahan itu positif dan aktif, perubahan yang bersifat positif dimaksud merupakan yang baik, bermanfaat, dan sesuai yang diharapkan individu. Sementara bersifat aktif, merupakan perubahan yang terjadi dalam diri individu sebagai implikasi dari usaha siswa melalui proses belajar dan perubahan tersebut terjadi secara alamiah. 
c. Perubahan itu efektif dan fungsional perubahan itu berhasil guna. Maksudnya adalah adalah perubahan yang bermakna dan bermanfaat bagi individu. Sedangkan perubahan bersifat funsional dan permanen dan siap dibutuhkan setiap saat.

Mencapai keberhasilan belajar seperti pendapat Syah tadi membutuhkan usaha yang maksisimal bagi lembaga pendidikan, salah satunya adalah peningkatan kreatifas guru dalam melaksanakan pembelajaran. Terlebih lagi guru pendidikan Agama Islam di sekolah umum yang merupakan ujung tombak dalam pembinaan mental peserta didik, dalam proses mengajar hendaklah menguasai model pembelajaran. Setelah menguasai model yang ingin diterapkan, menggunakan metode pembelajaran sesuai dengan materi yang diajarkan. Hal ini, memberikan pengalaman belajar yang menyenangkan bagi peserta didik. Selain itu, peserta didik lebih bersemangat dalam mengikuti proses belajar mengajar (Warsah, 2020b).

Sebagaimana telah dipakarkan pada data hasil penelitian menunjukkan bahwa kreativitas guru di SMKN Lubuk Ubar, Kabupaten Rejang Lebong, Bengkulu dalam pelaksanaan pembelajaran Pembelajaran Pendidikan Agama Islam tidak hanya menggunakan metode ceramah yang membuat peserta didik sebagai pendengar yang pasif. Akan tetapi mereka malakukan kerjasama dan interaksi yang baik antara peserta didik dan pendidik untuk mencapai tujuan belajar. Penerapan model pembelajarn kooperatif dan model pembelajaran aktif mereka jadikan sebagai solusi agar peserta didik termotivasi mengikuti pembelajaran PAI di sekolah tersebut. Tidak hanya itu ternyata banyak sekali manfaat yang diperoleh oleh siswa melalui model ini: siswa tidak hanya mengetahui isi materi yang diberikan, juga memahami essensi dari meteri tersebut.

Islam pun memberikan beberapa teknik dan metode yang diajarkan dalam Islam yang bisa menjadi masukan bagi para pendidik Pendidikan Agama Islam dan menjadi rujukan yang baik untuk diterapkan dalam proses belajar mengajar, terutama metode keteladanan. Kepala sekolah SMKN Lubuk Ubar dalam setiap kesempatan rapat memberikan himbauan kepada seluruh guru agar dapat menjaga sikap dan penampilan karena beliau sadar betul bahwa perilaku, tutur kata dan sikap guru akan menjadi teladan bagi peserta didik.

Kepala sekolah selalu menekankan bahwa perilaku guru, baik di depan kelas maupun di luar sekolah, sangat berpengaruh bagi pembentukan perilaku peserta didik. Untuk itu guru harus menjaga sikap di hadapan peserta didik. Secara tersirat hal ini merupakan bentuk kerja sama yang baik dan saling menghargai antar guru dan murid. Di samping itu juga guru memberikan kesempatan kepada setiap siswa untuk mengenmbangkan potensi mereka, termasuk berperan aktif dalam proses pemebelajaran pendidikan agama Islam di kelas. Melalui sikap keterbukaan satu dengan lain akan memberikan ruang anatara guru untuk memahami masing-masing karakter siswa, bahkan jika dalam proses belajar tersebut terjadi kesalahfamahan antara mereka, sikap saling memaafkan akan muncul sebagai solusi dari permasalahan itu (Warsah, 2020a). Keterlibatan siswa juga dapat menjadi faktor dalam meningkatkan motivasi belajar tersendiri bagi mereka. Perasaan dihargai oleh guru akan tumbuh dan semangat belajar akan meningkat sehingga pada akhirnya akan dapat mengantarkan mereka pada peningkatan hasil belajar yang lebih baik. 


\section{KESIMPULAN}

Penelitian ini memperoleh kesimpulan sebagai berikut: Model-model pembelajaran yang diterapkan oleh guru-guru PAI di SMK 03 Lubu Ubar Kabupaten Rejang Lebong, antara lain model pembelajaran aktif; yaitu model pembelajaran yang membawa siswa menjadi aktif dan kreatif, tidak hanya sekadar mendengarkan, akan tetapi juga melakukan kegiatan seperti memproses, menemukan, dan memanfaatkan informasi. Model lain yang digunakan oleh guru PAI adalah model pembelajaran kontektual. Model ini membantu pendidik mengaitkan antara materi yang diajarkan dengan situasi dunia nyata peserta didik, sehingga membuat peserta didik dapat menemukan hubungan antara pengetahuan yang dimilikinya dengan penerapanya dalam kehidupan mereka sebagai anggota keluarga dan masyarakat.

Beberapa faktor pendukung dan penghambat dalam penerapkan model pembelajaran dalam rangka meningkatkan hasil pembelajaran PAI siswa kelas XI SMK 03 Lubuk Ubar antara lain: dukungan, pembinaan dan apresiasi dari kepala sekolah; berbagi pengalaman dan informasi serta media pembelajaran yang tersedia di sekolah tersebut menjadi factor pendukung terlaksananya penerapan model pembelajaran PAI di kelas. Adapun faktor penghambat yang prinsip belum banyak ditemukan oleh guru.telah diperoleh pemahaman dari keterangan sebelumnya bahwa model pembelajaran pendidikan agama islam adalah suatu rancangan yang di dalamnya menggambarkan sebuah proses pembelajaran yang dapat dilaksanakn oleh guru dalam mentransfer pengetahuan maupun nilai-nilai kepada peserta didik sehingga diharapkan peserta didik dapat meyakini, memahami, menghayati, dan mengamalkan ajaran Islam.

\section{DAFTAR PUSTAKA}

Abdul, M. R., Rostitawati, T., Podungge, R., \& Arif, M. (2020). Pembentukan Akhlak Dalam Memanusiakan Manusia: Perspektif Buya Hamka. Pekerti, 2(1), 79-99

Ahmadi, A. (2017). Peran Pendidikan Agama Islam Dalam Membina Para Remaja [Diploma, UIN Sultan Maulana Hasanudin Banten]. http://repository.uinbanten.ac.id/633/

Amin, A. (2017). Pengembangan Bahan Ajar Pai Aspek Akhlaq Berbasis Pendekatan Pembelajaran Demokratik Dalam Meningkatkan Pemahaman Konsep Siswa SMPN 12 Kota Bengkulu. Manhaj: Jurnal Penelitian Dan Pengabdian Masyarakat, 6(3), Article 3. https://doi.org/10.1161/.v5i3.755

Anasri, A. (2019). Membentuk karakter dengan al-Qur'an, Satu Perspektif Pendidikan Islam. AlFikra: Jurnal Ilmiah Keislaman, 17(2), 218-248.

Anwar, S. (2018). Pendidikan Islam dalam Membangun Karakter Bangsa di Era Milenial. AlTadzkiyyah: Jurnal Pendidikan Islam, 9(2), 233-247.

Ardiana, N. (2018). Pengaruh Penggunaan Model Pembelajaran Group Investigation Terhadap Kemampuan Komunikasi Matematis Siswa. Jurnal Education And Development, 5(2), 33-33.

Arifin, H. Z. (2017). Perubahan Perkembangan Perilaku Manusia Karena Belajar. SABILARRASYAD: Jurnal Pendidikan dan Ilmu Kependidikan, 2(1), Article 1. http://jurnal.dharmawangsa.ac.id/index.php/sabilarrasyad/article/view/116

Ariyanti, T. (2016). Pentingnya Pendidikan Anak Usia Dini Bagi Tumbuh Kembang Anak The Importance Of Childhood Education For Child Development. Dinamika Jurnal Ilmiah Pendidikan Dasar, 8(1), Article 1. https://doi.org/10.30595/dinamika.v8i1.943 
Asnawan, A. (2020). Relevansi Kebijakan dalam Peningkatan Mutu Pendidikan Agama Islam. Tafhim Al-'Ilmi, 11(2), 223-240.

Astuti, W., \& Kristin, F. (2017). Penerapan Model Pembelajaran Teams Games Tournament Untuk Meningkatkan Keaktifan dan Hasil Belajar IPA. Jurnal Ilmiah Sekolah Dasar, 1(3), 155-162.

Daheri, M., \& Warsah, I. (2019). Pendidikan Akhlak: Relasi Antara Sekolah Dengan Keluarga. At-Turats: Jurnal Pemikiran Pendidikan Islam, 13(2), 1-20.

Desstya, A., Novitasari, I. I., Razak, A. F., \& Sudrajat, K. S. (2017). Refleksi pendidikan IPA sekolah dasar di Indonesia (relevansi model pendidikan Paulo Freire dengan pendidikan IPA di sekolah dasar). Profesi Pendidikan Dasar, 1(1), 1-11.

Dewi, M. R., Mudakir, I., \& Murdiyah, S. (2016). Pengaruh Model Pembelajaran Kolaboratif berbasis Lesson Study terhadap Kemampuan Berpikir Kritis Siswa. Jurnal Edukasi, 3(2), 29-33. https://doi.org/10.19184/jukasi.v3i2.3526

Ekawati, R., Susetyarini, E., Pantiwati, Y., \& Husamah, H. (2016). Peningkatan Hasil Belajar Dan Kemampuan Berpikir Kritis dengan Model Pembelajaran Cooperative Integrated Reading And Composition (CIRC). JPBI (Jurnal Pendidikan Biologi Indonesia), 1(3), Article 3. https://doi.org/10.22219/jpbi.v1i3.2662

Elyas, A. H. (2018). Penggunaan Model Pembelajaran E-Learning dalam Meningkatkan Kualitas Pembelajaran. Warta Dharmawangsa, 0(56), Article 56. http://jurnal.dharmawangsa.ac.id/index.php/juwarta/article/view/4

Emda, A. (2018). Kedudukan Motivasi Belajar Siswa dalam Pembelajaran. Lantanida Journal, 5(2), 172-182. https://doi.org/10.22373/lj.v5i2.2838

Fachri, M. (2014). Urgensi Pendidikan Agama Islam dalam Pembentukan Karakter Bangsa. $A T$ TURAS: Jurnal Studi Keislaman, 1(1), Article 1. https://doi.org/10.33650/atturas.v1i1.156

Haeruman, L. D., Rahayu, W., \& Ambarwati, L. (2017). Pengaruh Model Discovery Learning Terhadap Peningkatan Kemampuan Berpikir Kritis Matematis Dan Self-Confidence Ditinjau Dari Kemampuan Awal Matematis Siswa Sma Di Bogor Timur. JPPM (Jurnal Penelitian dan Pembelajaran Matematika), 10(2), Article 2. https://doi.org/10.30870/jppm.v10i2.2040

Hashimov, E. (2015). Qualitative Data Analysis: A Methods Sourcebook and The Coding Manual for Qualitative Researchers: Matthew B. Miles, A. Michael Huberman, and Johnny Saldaña. Thousand Oaks, CA: SAGE, 2014. 381 pp. Johnny Saldaña. Thousand Oaks, CA: SAGE, 2013. 303 pp. Taylor \& Francis.

Hidayah, R. N. (2015). Pendidikan Anak Usia Dini Perspektif Ki Hajar Dewantara. Al-Mabsut: Jurnal Studi Islam dan Sosial, 9(2), 249-258.

Ilham, I. (2019). Sinergisitas Pendidikan Islam: Model Sinergisitas Lembaga Pendidikan Islam di Indonesia. TAJDID: Jurnal Pemikiran Keislaman Dan Kemanusiaan, 3(2), 236-258.

Jamil, M. M. (2019). Optimalisasi Model ARCS Dalam Pembelajaran Saintifik Untuk Meningkatkan Motivasi Belajar Peserta Didik Pada Peminatan Mata Pelajaran Geografi Di Kelas Matematika Ilmu Alam. IJIS Edu: Indonesian Journal of Integrated Science Education, 1(1), 7-24. https://doi.org/10.29300/ijisedu.v1i1.1401 
Kusumawati, T. (2016). Metode Penanaman Nilai-Nilai Agama dan Moral pada Pendidikan Anak Usia Dini (PAUD) Al Amanah Desa Gembong Kecamatan Bojongsari Kabupaten Purbalingga Tahun Pelajaran 2013/2014 [PhD Thesis]. IAIN Purwokerto.

Laili, H. (2016). Pengaruh Model Pembelajaran Contextual Teaching and Learning (CTL) dalam Meningkatkan Kemampuan Pemecahan Masalah Matematika Siswa MTs Nurul Hakim Kediri Ditinjau dari Segi Gender. PALAPA, 4(2), 34-52. https://doi.org/10.36088/palapa.v4i2.22

Magta, M. (2013). Konsep Pendidikan Ki Hajar Dewantara Pada Anak Usia Dini. Jurnal Pendidikan Usia Dini, 7(2), 221-232.

Marzuki, A. (2017). Model-Model Pembelajaran PAI Inovatif dan Kontekstual. Al-GHAZWAH, $1(1), 103-116$.

Miles, M. B., Huberman, M. A., \& Saldana, J. (2014). Drawing and verifying conclusions. Qualitative data analysis: A methods sourcebook.

Moleong, L. J. (2010). Methodology of Qualitative Research. Bandung: Remaja Rosda Karya.

Mustaqim, A. (2017). Pendidikan Humanisme Ki Hajar Dewantara. Tafhim Al-'Ilmi, 9(2).

Nasution, M. K. (2018). Penggunaan Metode Pembelajaran Dalam Peningkatan Hasil Belajar Siswa. Studia Didaktika, 11(01), 9-16.

NGAZIZAH, N. (2019). Pengaruh Model Pembelajaran Kooperatif Tipe Twostay Two Stray (TSTS) Terhadap Motivasi Dan Hasil Belajar Akidah Akhlak SISWA KELAS VIII di MTs AL Huda Bandung Tulungagung.

Noor, T. (2018). rumusan tujuan pendidikan nasional pasal 3 undang-undang sistem pendidikan nasional No 20 Tahun 2003. Wahana Karya Ilmiah, 3(01).

Nurdyansyah, N. (2016). Developing ICT-Based Learning Model to Improve Learning Outcomes IPA of SD Fish Market in Sidoarjo. Jurnal TEKPEN, 1(2), Article 2. https://journal.unesa.ac.id/index.php/jtp/article/view/1137

Roulston, K. (2014). Analysing interviews. The SAGE Handbook of Qualitative Data Analysis, 297-312.

Saihu, S. (2019). Konsep Manusia dan Implementasinya dalam Perumusan Tujuan Pendidikan Islam Menurut Murtadha Muthahhari. Andragogi: Jurnal Pendidikan Islam dan Manajemen Pendidikan Islam, 1(2), 197-217. https://doi.org/10.36671/andragogi.v1i2.54

Semiawan, C. R. (2010). Metode Penelitian Kualitatif. Grasindo.

Setiawan, A. A., Johan. (2018). Metodologi penelitian kualitatif. CV Jejak (Jejak Publisher).

Setiawan, A., \& Basyari, I. W. (2017). Desain Bahan Ajar Yang Berorientasi Pada Model Pembelajaran Student Team Achievement Division Untuk Capaian Pembelajaran Pada Ranah Pemahaman Siswa Pada Mata Pelajaran IPS Kelas VII SMP Negeri 1 Plered Kabupaten Cirebon. Edunomic: Jurnal Ilmiah Pendidikan Ekonomi Fakultas Keguruan dan Ilmu Pendidikan, 5(1), 17-32. https://doi.org/10.33603/ejpe.v5i1.431

Setiawan, E. (2012). Kamus besar bahasa Indonesia (KBBI). Badan Pengembangan Dan Pembinaan Bahasa, Kemdikbud (Pusat Bahasa), 2016.

Sugiarto, E. (2017). Menyusun Proposal Penelitian Kualitatif: Skripsi dan Tesis: Suaka Media. Diandra Kreatif.

Sutiah, S. (2020). Pengembangan Model Pembelajaran Pendidikan Agama Islam. NLC. 
Suwendra, I. W. (2018). Metodologi penelitian kualitatif dalam ilmu sosial, pendidikan, kebudayaan dan keagamaan. Nilacakra.

Syafe'i, I. (2015). Tujuan Pendidikan Islam. Al-Tadzkiyyah: Jurnal Pendidikan Islam, 6(2), 151166. https://doi.org/10.24042/atjpi.v6i2.1876

Syaodih, E., \& Wulansari, R. (2019). Meningkatkan Pemahaman Konsep Peta Menggunakan Metode Pembelajaran Bervariasi. EDUCARE, 84-89. https://doi.org/10.36555/educare.v17i2.246

Syaparuddin, S., Meldianus, M., \& Elihami, E. (2020). Strategi Pembelajaran Aktif Dalam Meningkatkan Motivasi Belajar PKn PESERTA DIDIK. Mahaguru: Jurnal Pendidikan Guru Sekolah Dasar, 1(1), 30-41.

Warsah, I. (2018). Pendidikan Keimanan Sebagai Basis Kecerdasan Sosial Peserta Didik: Telaah Psikologi Islami. Psikis: Jurnal Psikologi Islami, 4(1), 1-16. https://doi.org/10.19109/psikis.v4i1.2156

Warsah, I. (2020a). Forgiveness Viewed from Positive Psychology and Islam. Islamic Guidance and Counseling Journal, 3(2), 108-121.

Warsah, I. (2020b). Islamic Psychological Analysis Regarding To Raḥmah Based Education Portrait At Iain Curup. Psikis: Jurnal Psikologi Islami, 6(1), 29-41. https://doi.org/10.19109/psikis.v6i1.3941

Warsah, I., Angdreani, V., \& Karolina, A. (2020). Implementasi Metode Pembiasaan: Upaya penanaman nilai-nilai islami siswa SDN 08 Rejang Lebong. At-Ta'lim : Media Informasi Pendidikan Islam, 19(1), Article 1. https://doi.org/10.29300/attalim.v19i1.3207

Warsah, I., \& Nuzuar, N. (2018). Analisis Inovasi Administrasi Guru dalam Meningkatkan Mutu Pembelajaran (Studi Man Rejang Lebong). Edukasi, 16(3), 294572.

Yasyakur, M. (2017). Model Pembelajaran Berkarakter dalam Perspektif Al-Quran (Pada Sekolah Islam Terpadu Full Day School). Edukasi Islami: Jurnal Pendidikan Islam, 6(11), 20. https://doi.org/10.30868/ei.v6i11.96

Zuhdiyah, Z. (2018). Pengembangan Bahan Ajar PAI SMP NU Palembang Berbasis Kemampuan Otak. Intizar, 24(2), 253-264. https://doi.org/10.19109/intizar.v24i2.3128 